\title{
PENGARUH TINGKAT KOMITMEN ORGANISASI TERHADAP TINGKAT KINERJA KARYAWAN DI DEPARTEMEN WAREHOUSE PT. X
}

\author{
Vivin Wulandari ${ }^{1}$, Idha Rahayuningsih ${ }^{2}$ \\ Universitas Muhammadiyah Gresik
}

\begin{abstract}
Abstrak
Tujuan penelitian untuk membuktikan ada tidaknya pengaruh antara komitmen organisasi terhadap kinerja karyawan di Departemen Warehouse di PT. X. Jenis penelitian kuantitatif. Populasi sebanyak 42 karyawan di Departemen Warehouse, dengan teknik sampling jenuh. Skala komitmen kerja terdiri dari 35 item dengan koefisien reliabilitas Alpha Cornbach 0,94.Formulir penilaian kinerja terdiri dari 23 item.Pengumpulan data dari variabel kinerja menggunakan form penilaian kinerja, dengan koefisien reliabilitas Alpha Cornbach 0,927. Analisis data menggunakan teknik regresi sederhana. Nilai $t=$ 4.634 dengan $\mathrm{p}=0,00<0,05$, berarti komitmen organisasi berpengaruh secara signifikan terhadap perubahan nilai variabel kinerja. $\mathrm{R}$ Square sebesar 0,349 yang menunjukkan bahwa sumbangan efektif komitmen organisasi terhadap kinerja karyawan sebesar $34,9 \%$, sedangkan sisanya $65,1 \%$ dipengaruhi variabel lain yang tidak diteliti.
\end{abstract}

Kata kunci: Komitmen organisasi, Kinerja Karyawan

\begin{abstract}
The research objective is to prove impact organizational commitment to the performance of employees in the Warehouse Department at PT. X. Type of quantitative research. The population is 42 employees in the Warehouse Department, with saturated sampling techniques. The work commitment scale consists of 35 items with a Cornbach Alpha reliability coefficient of 0.94. Performance collection using the performance appraisal consists of 23 items, with Cornbach Alpha reliability coefficient 0.927. Data analysis using simple regression techniques. The value of $t=4.634$ with $p=0.00<0.05$, means that organizational commitment has a significant effect on changes in the value of the performance variable. $R$ Square is 0.349 which indicates that the effective contribution of organizational commitment to employee performance is $34.9 \%$, while the remaining $65.1 \%$ is influenced by other variables not examined.
\end{abstract}

Key Word : Organizational Commitment, Performance Appraisal

1email: vivinwulandari2802@gmail.com

Fakultas Psikologi Universitas Muhammadiyah Gresik

Jalan Sumatra No 101 Gresik

Pengaruh Tingkat Komitmen Organisasi Terhadap Tingkat Kinerja Karyawan Di Departemen

Warehouse PT. X

Vivin Wulandari, Idha Rahayuningsih 


\section{Pendahuluan}

Seiring dengan bertumbuhnya percepatan pembangunan negeri diiringi pula dengan tingginya permintaan semen sebagai bahan baku dasar, oleh karena itu PT. X hadir sebagai salah satu produsen semen untuk memenuhi kebutuhan pasar. PT.X adalah salah satu perusahaan swasta di Kabupaten Gresik yang memproduksi semen sebagai bahan baku bangunan. PT.X memiliki total 300 karyawan yang terbagi menjadi beberapa departemen yaitu produksi, pemeliharaan, SHE, HRGA, keuangan dan warehouse.

Karyawan merupakan aset terpenting dalam pencapaian tujuan organisasi,sehingga karyawan yang mampu menghasilkan kinerja yang baik akan mampu memberikan kontribusi besar dalam menjalankan aktivitas suatu organisasi.Kinerja adalah hasil kerja yang dapat dicapai oleh seseorang atau sekelompok orang dalam suatu organisasi, sesuai dengan wewenang dan tanggung jawab masing-masing dalam rangka mencapai tujuan organisasi yang bersangkutan secara legal, tidak melanggar hukum, dan sesuai dengan moral maupun etika (Rachmawati, 2009).

Kinerja adalah hasil atau tingkat keberhasilan seseorang secara keseluruhan selama periode tertentu dalam melaksanakan tugas dibandingkan dengan berbagai kemungkinan, Warehouse sepertistandar hasil kerja, target atau sasaran ataukriteria yang telah ditentukan terlebih dahulu, telah disepakati bersama (Rivai dan Basri, 2005).Kinerja karyawan merupakan suatu hal yang sangat penting dalam upaya perusahaan untuk mencapai tujuannya (Subekhi dan Jauhar, 2012).

Bertambahnya jumlah produksi mempengaruhi tingginya kebutuhan bahan baku semen. Hal tersebut menuntut departemen warehouse untuk terus menjaga kinerja karyawan dengan baik. Departemen Warehouse merupakan departemen yang mengurusi penerimaan, pengelolaan dan pengeluaran baik bahan baku (raw material) dan barang jadi (finished goods). Semua barang yang disimpan di warehouse harus dijaga dengan baik dan benar. Seluruh proses penerimaan, penyimpanan dan pengeluaran material harus dipastikan sesuai dengan standar yang telah ditetapkan oleh perusahaan. Seluruh karyawan Departemen Warehouse harus memastikan dan mengontrol secara berkala ketersediaan material sebagai bahan dasar pembuatan semen. Sebagai departemen penerima bahan baku maka seluruh karyawan dituntut untuk memiliki kinerja yang baik guna mendukung lancarnya proses produksi.

Berdasarkan Key Performance Index (KPI) menunjukkan bahwa pada semester pertama pada tahun 2017 Departemen Warehouse tidak dapat mencapai target yang telah ditetapkan. Departemen Warehouse menetapkan target Raw Material Availability pada angka rata-rata $83 \%$ namun rata-rata pencapainnya hanya $71,91 \%$. Bag Cement Availability $83 \%$ tetapi rata-rata pencapainnya 82\%.Sparepart Availability rata-rata target capaian $83 \%$ sedangkan rata-rata 
capaiannya 82\%. Hal ini tentu menunjukkan kurang maksimalnya kinerja karyawan dalam proses penerimaan, pengelolaan dan pengeluaran material, belum mampu menyentuh target yang telah ditetapkan. Selain hasil data Key Performance Index (KPI) yang menunjukkan kinerja dibawah target, hasil skor audit 5R Departemen Warehouse juga menunjukkan prestasi terbawah diantara departemen lainnya pada Bulan Februari-Juli 2017.

Berdasarkan skor audit 5R terlihat bahwa pada Bulan Februari Departemen Warehouse PT.X bersama Departemen Produksi berada pada posisi terbawah dalam penilaian 5R jika dibandingkan dengan departemen lainnya. Pada Bulan Maret dan April Departemen Warehouse berhasil mendapat penilaian lebih baik dibandingkan Departemen Produksi.Namun pada Bulan Mei sampai dengan Juli 2017 Departemen Warehouse konsisten mendapatkan penilaian 5R terendah dibandingkan departemen- lainnya. Hasil penilaian skor audit 5R ini tentu menjadi salah satu permasalahan yang mengindikaikan penurunan kinerja karyawan.

Pendapat Luthans (2006) faktor yang mempengaruhi kinerja pegawai adalah kompensasi, gaji, kepemimpinan,komitmen kerja, lingkungan atau suasana kerja, budaya organisasi, keterlibatan dalam organisasi, dan disiplin kerja. Faktor lain yang mempengaruhi kinerja menurut Hasibuan (2007) yakni komitmen organisasi, disiplin kerja, kepemimpinan, kompensasi dan budaya organisasi.

Mathis dan Jackson (2002) menjelaskan komitmen organisasi adalah tingkat kepercayaan dan penerimaan tenaga kerja terhadap tujuan organisasi dan mempunyai keinginan untuk tetap ada di dalam organisasi tersebut yang pada akhirnya tergambar dalam statistik ketidakhadiran dan masuk keluar tenaga kerja (turnover).

Karyawan dengan komitmen organisasi yang tinggi memiliki perbedaan sikap dibandingkan yang berkomitmen rendah. Komitmen organisasi yang tinggi menghasilkan performa kerja, rendahnya tingkat absen, dan rendahnya tingkat keluar-masuk (turnover) karyawan.Karyawan yang berkomitmen tinggi akan memiliki produktivitas tinggi (Luthans, 2006).Sebaliknya, komitmen karyawan yang rendah memiliki dampak negatif. Setiap organisasi akan mengalami kesulitan jika komitmen karyawannya rendah. Karyawan dengan komitmen yang rendah tidak akan memberikan yang terbaik kepada organisasi dan dengan mudahnya keluar organisasi (Riady, 2003).

Berdasarkan uraian masalah yang terkait dengan kinerja karyawan, maka peneliti tertarik untuk meneliti pengaruh komitmen organisasi terhadap kinerja karyawan di Departemen Warehouse PT. X.

Pengaruh Tingkat Komitmen Organisasi Terhadap Tingkat Kinerja Karyawan Di Departemen 


\section{Metode Penelitian}

Penelitian ini merupakan tipe kuantitatif dengan analisis regresi.Teknik sampling jenuh digunakan dalam penelitian ini sehingga sampel penelitian diambil seluruh anggota populasi. Subyek keseluruhan berjumlah 42 karyawan bagian lapangan di Departemen Warehouse PT.X.

Variabel penelitian terdiri dari variabel terikat yaitu tingkat kinerja karyawan dan variabel bebas yaitu tingkat komitmen organisasi. Komitmen kerja diukur dengan skala likert yang terdiri dari 35 item valid dengan koefisien reliabilitas Alpha Cornbach 0,94. Tiap item dilengkapi dengan empat pilihan jawaban yang meliputi Sangat Sesuai, Sesuai, Tidak Sesuai, Sangat Tidak Sesuai. Pengumpulan data dari variabel kinerja menggunakan form penilaian kinerja terdiri dari 23 item, dengan koefisien reliabilitas Alpha Cornbach 0,927.

Teknik analisis data menggunakan regresi sederhana, sebelum menganalisis data maka dilakukan uji asumsi yaitu normalitas dan linieritas. Proses analisis menggunakan SPSS.18.0 for windows.

\section{Hasil Penelitian dan Pembahasan}

Uji normalitas ini menggunakan Norma Q-Q Plotmelalui SPSS 18.0 for Windows. dengan operasi Analyze > Descriptive Statistics > Q-Q Plot. Dalam pengajuan normalitas diperoleh sebaran data kdua variabel sudah memenuhi normalitas, karena sebaran data sudah mendekati garis diagonal

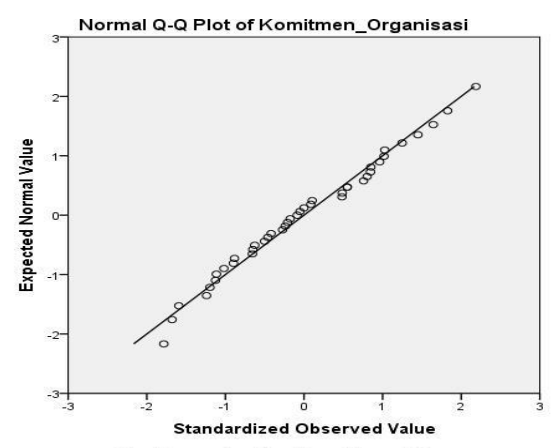

Gambar 1. Hasil Uji Normalitas Variabel Komitmen Organisasi 


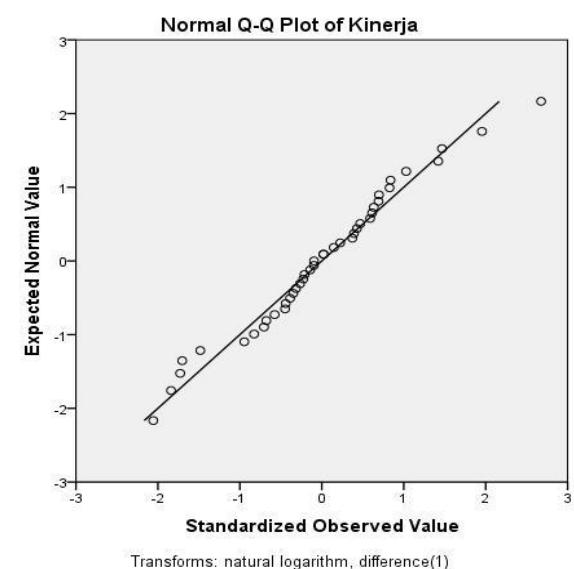

Gambar 2. Hasil Uji Normalitas Variabel Kinerja karyawan

Uji linieritas dilakukan dengan bantuan SPSS 18.0 for Windows dengan menggunakan operasi Analyze>Compare Means. Means dua variabel dikatakan mempunyai hubungan yang linear bila signifikansi (linearity) kurang dari 0,05 (Priyatno, 2008). Hasil uji linearitas nilai $\mathrm{p}=0,000<0,05$ maka dapat disimpulkan bahwa antara variabel komitmen organisasi dengan kinerja karyawan terdapat hubungan yang linier.

Hasil analisis data korelasi Product Moment menunjukkan angka $r=0,591$ dengan $\mathrm{p}=0,000<0,05$. Sehingga dapat disimpulkan bahwa terdapat hubungan yang signifikan antara komitmen organisasi dengan kinerja karyawan. Nilai $\mathrm{R}$ Square sebesar 0,349. Hal tersebut menunjukkan bahwa sumbangan komitmen organisasi terhadap kinerja karyawan sebesar 34,9\%, sedangkan sisanya $65,1 \%$ dipengaruhi variabel lain yang tidak diteliti.

Nilai t statistik untuk variabel komitmen organisasi sebesar 4,634 dengan nilai $\mathrm{p}=0,00<0,05$. Hal tersebut dapat disimpulkan bahwa ada pengaruh yang signifikan antara komitmen organisasi dengan kinerja karyawan. Nilai $F=21,473$ dengan nilai $\mathrm{p}=0,000<0,05$. Hal tersebut berarti persamaan garis regresi $\mathrm{Y}$ $=41.253+0.972 \mathrm{X}$ adalah good fit untuk memprediksi kinerja.

Hasil penelitian ini sesuai dengan teori yang dikemukakan oleh Pendapat Luthans (2006) faktor yang mempengaruhi kinerja pegawai salah satunya adalahnya komitmen organisasi, selain faktor -faktor lain seperti kompensasi, gaji, kepemimpinan, lingkungan atau suasana kerja, budaya organisasi, keterlibatan dalam organisasi, dan disiplin kerja.

Koefisien determinasi $\left(r^{2}\right)$ dari $r=0,591^{2}=0,349$, artinya, $r^{2}=0,349(34,9 \%)$ menginformasikan bahwa sumbangan komitmen organisasi terhadap kinerja karyawan sebesar $34,9 \%$, sedangkan sisanya $65,1 \%$ dipengaruhi variabel lain yang

Pengaruh Tingkat Komitmen Organisasi Terhadap Tingkat Kinerja Karyawan Di Departemen 
tidak diteliti. Seperti yang dikemukakan oleh Hasibuan (2007) faktor yang mempengaruhi kinerja yakni komitmen organisasi, disiplin kerja, kepemimpinan, kompensasi dan budaya organisasi.

Berikut ini disajikan tabel sebaran sikap dan perilaku yang menunjukkan komitmen organisasi terhadap kinerja karyawan Departemen Warehouse PT.X Kabupaten Gresik, yaitu :

Tabel 1. Item Komitmen Organisasi Sebagian Besar Dipilih Responden

\begin{tabular}{|c|c|c|c|c|c|}
\hline \multirow[b]{2}{*}{ No. } & \multirow[b]{2}{*}{ Indikator } & \multirow[b]{2}{*}{ Pernyataan } & \multicolumn{3}{|c|}{ Presentase } \\
\hline & & & $\begin{array}{l}\text { Sangat } \\
\text { Setuju } \\
\text { (4) }\end{array}$ & $\begin{array}{l}\text { Setuju } \\
\text { (3) }\end{array}$ & $\begin{array}{l}\text { Total } \\
\%\end{array}$ \\
\hline 15 & $\begin{array}{l}\text { Penerimaan } \\
\text { terhadap tujuan } \\
\text { organisasi }\end{array}$ & $\begin{array}{l}\text { Saya merasa bahwa } \\
\text { perusahaan ini memiliki } \\
\text { arti penting bagi saya }\end{array}$ & $35.7 \%$ & $38.1 \%$ & $73.8 \%$ \\
\hline 33 & $\begin{array}{l}\text { Hasrat untuk } \\
\text { bertahan menjadi } \\
\text { bagian dari } \\
\text { organisasi }\end{array}$ & $\begin{array}{l}\text { Saya merasa rugi jika } \\
\text { keluar dari perusahaan }\end{array}$ & $23.8 \%$ & $47.6 \%$ & $71.4 \%$ \\
\hline 39 & $\begin{array}{l}\text { Hasrat untuk } \\
\text { bertahan menjadi } \\
\text { bagian dari } \\
\text { organisasi }\end{array}$ & $\begin{array}{l}\text { Saya merasa } \\
\text { perusahaan memenuhi } \\
\text { kebutuhan hidup saya }\end{array}$ & $26.2 \%$ & $45.2 \%$ & $71.4 \%$ \\
\hline
\end{tabular}

Pada Tabel 1. item komitmen organisasi yang cenderung paling banyak dipilih responden yaitu : nomer 15 dengan prosentase 73,8\%, yaitu Saya merasa bahwa perusahaan ini memilki arti penting bagi saya. Diikuti dengan pernyataan nomer 33 "Saya merasa rugi jika keluar dari perusahaan" dengan prosentase $71,4 \%$. Kemudian pernyataan nomer 39 "Saya merasa perusahaan dapat memenuhi kebutuhan hidup saya" mendapat prosentase sebesar 71,4\%.

Data yang terdapat pada tabel 1 tersebut menunjukkan bahwa bahwa sebagian besar komitmen organisasi yang dimiliki karyawan Departemen Warehouse PT. X termasuk jenis komitmen organisasi berkelanjutan (continuence commitment). Meyer dan Allen (dalam Mas'ud; 2002:36) bahwa yang dimaksud komitmen organisasi berkelanjutan (continuence commitment) adalah karyawan merasa membutuhkan untuk tetap tinggal (bekerja di perusahaan).Karyawan macam ini merasa terjerat dengan perusahaan karena kurang mempunyai keterampilan (skills), atau tidak ada kesempatan untuk pindah ke perusahaan lain, atau menerima gaji yang sangat tinggi, dan lain sebagainya. Mereka berfikir bahwa meninggalkan perusahaan akan sangat merugikan. 
Tabel 2. Item Komitmen Organisasi yang Sedikit Dipilih Responden

\begin{tabular}{|c|c|c|c|c|c|}
\hline No. & Indikator & Pernyataan & $\begin{array}{l}\text { Sangat } \\
\text { Setuju } \\
\text { (4) }\end{array}$ & $\begin{array}{l}\text { Setuju } \\
\text { (3) }\end{array}$ & Total \% \\
\hline 1 & $\begin{array}{l}\text { Hasrat untuk } \\
\text { Bertahan menjadi } \\
\text { bagian dari organisasi }\end{array}$ & $\begin{array}{l}\text { Saya merasa senang berkarir } \\
\text { perusahaan ini }\end{array}$ & $9.5 \%$ & $35.7 \%$ & $45.2 \%$ \\
\hline 37 & $\begin{array}{l}\text { Penerimaan } \\
\text { terhadap tujuan } \\
\text { organisasi }\end{array}$ & $\begin{array}{l}\text { Saya mendukung visi } \\
\text { perusahaan }\end{array}$ & $21.4 \%$ & $26.2 \%$ & $47.6 \%$ \\
\hline 25 & $\begin{array}{l}\text { Keinginan bekerja } \\
\text { keras }\end{array}$ & $\begin{array}{l}\text { Saya merasa } \\
\text { permasalahan perusahaan } \\
\text { menjadi masalah saya juga }\end{array}$ & $19.0 \%$ & $31.0 \%$ & $50.0 \%$ \\
\hline
\end{tabular}

Berdasarkan tabel 2 diatas, terlihat bahwa item komitmen kerja yang sedikit dipilih karyawan Departemen Warehouse PT.X Kabupaten Gresik antara lain item nomor 1, 37 dan 25. Hal itu berarti hanya 45,2\% karyawan merasa bahagia berkarir di perusahaan; hanya 47,6\% karyawan yang mendukung visi perusahaan; hanya $50 \%$ karyawan yang merasa permasalahan perusahaan menjadi masalahnya juga.Data tersebut menunjukkan bahwa hanya sebagian kecil karyawan Departemen Warehouse PT.X yang memiliki komitmen organisasi.

Tabel 3. Item Kinerja Karyawan yang dinilai Tinggi oleh Supervisor

\begin{tabular}{cllc} 
No. & Indikator & Pernyataan & Prosentase \\
\hline 7 & Ketepatan Waktu & $\begin{array}{l}\text { Penerimaan material, paper } \\
\text { bag dan material tepat waktu }\end{array}$ & $71.5 \%$ \\
23 & Competency Behaviour & $\begin{array}{l}\text { Berusaha keras untuk } \\
\text { mencapai target dan prestasi }\end{array}$ & $71.5 \%$ \\
& & $\begin{array}{l}\text { tinggi } \\
\text { Jumlah Sparepart stabil } \\
\text { diantara minimal dan } \\
\text { maksimal stock }\end{array}$ & $71,4 \%$ \\
\hline
\end{tabular}

Kinerja karyawan mempengaruhi seberapa banyak mereka memberikan kontribusi kepada organisasi, antara lain termasuk kuantitas output, kualitas output, jangka waktu output, kehadiran di tempat kerja dan sikap kooperatif.

Kinerja karyawan dinilai sudah berkontribusi dengan baik untuk perusahaan walaupun belum sepenuhnya. Pernyataan tersebut sesuai dengan yang dikemukakan oleh Mathis (2002:78) bahwa kinerja pada dasarnya adalah

Pengaruh Tingkat Komitmen Organisasi Terhadap Tingkat Kinerja Karyawan Di Departemen 
apa yang dilakukan atau tidak dilakukan karyawan. Pada tabel 3 diatas, ketiga item yaitu nomer 7, 23, 3 dan 24 menunjukkan aspek kinerja karyawan yang dinilai tinggi supervisor pada sebagian besar karyawan. Pada item 7 menunjukkan terdapat $71,5 \%$ karyawan yang menerima material, paper bag dan material tepat waktu; item 23 terdapat 71,5\% karyawan berusaha keras untuk mencapai target dan prestasi tinggi; item 3 terdapat $71,4 \%$ karyawan yang mampu menjaga stabilitas jumlah sparepart diantara minimal dan maksimal stock.

Tabel 4. Item Kinerja Karyawan yang dinilai Tinggi oleh Supervisor tetapi Hanya Sedikit Karyawan

\begin{tabular}{rlll}
\hline No. & \multicolumn{1}{c}{ Indikator } & \multicolumn{1}{c}{ Pernyataan } & Prosentase \\
\hline 4 & $\begin{array}{l}\text { Kualitas Hasil } \\
\text { Kerja }\end{array}$ & Kualitas material terjaga dengan baik & $35,7 \%$ \\
11 & $\begin{array}{l}\text { Behaviour } \\
\text { Competency }\end{array}$ & $\begin{array}{l}\text { Memiliki semangat kekeluargaan } \\
\text { yang didasari loyalitas tinggi }\end{array}$ & $42,9 \%$ \\
15 & $\begin{array}{l}\text { Behaviour } \\
\text { Competency }\end{array}$ & $\begin{array}{l}\text { Melakukan tindakan yang konsisten } \\
\text { dengan nilai (value) dan keyakinannya } \\
\text { (beliefs) }\end{array}$ & $47,6 \%$ \\
13 & $\begin{array}{l}\text { Behaviour } \\
\text { Competency }\end{array}$ & Mengetahui nilai-nilai dan kode etik & $47,6 \%$ \\
\hline
\end{tabular}

Berdasarkan tabel 4 diatas, terlihat bahwa item kinerja yang dinilai baik oleh supervisor tetapi hanya sedikit karyawan memperoleh nilai baik tersebut, meliputi item nomer 4, 11, 15, dan 13. Artinya hanya 35,7\% karyawan yang mampu menjaga kualitas material dengan baik; hanya 42,9\% memiliki semangat kekeluargaan yang didasari loyalitas tinggi; hanya 47,6\% melakukan tindakan yang konsisten dengan nilai (value) dan keyakinannya (beliefs) dan 47,6\% mengetahui nilai-nilai dan kode etik.

Handoko (1994:20) menjelaskan fungsi penilaian kinerja, sebagai dasar untuk menentukan keputusan penggajian dapat juga digunakan sebagai dasar umpan balik atas kinerja yang dilakukan karyawan.Rendahnya prosentase yang didapat karyawan Departemen Warehouse PT.X pada kualitas hasil kerja dan behaviour competency dapat menjadi feedback bagi perusahaan untuk mengevaluasi kekurangan dari dua aspek tersebut agar tidak ikut berdampak juga pada rendahnya kualitas output produk yang dihasilkan oleh perusahaan.

\section{Kesimpulan}

Hasil analisis data korelasi Product Moment menunjukkan angka $\mathrm{r}=0,591$ dengan $\mathrm{p}=0,000<0,05$. Sehingga dapat disimpulkan bahwa terdapat hubungan yang signifikan antara komitmen organisasi dengan kinerja karyawan. Nilai $\mathrm{R}$ 
Square sebesar 0,349. Hal tersebut menunjukkan bahwa sumbangan komitmen organisasi terhadap kinerja karyawan sebesar 34,9\%, sedangkan sisanya 65,1\% dipengaruhi variabel lain yang tidak diteliti.

Nilai t statistik untuk variabel komitmen organisasi sebesar 4,634 dengan nilai $\mathrm{p}=0,00<0,05$. Hal tersebut dapat disimpulkan bahwa ada pengaruh yang signifikan antara komitmen organisasi dengan kinerja karyawan. Nilai $F=21,473$ dengan nilai $\mathrm{p}=0,000<0,05$. Hal tersebut berarti persamaan garis regresi $\mathrm{Y}$ $=41.253+0.972 \mathrm{X}$ adalah good fit untuk memprediksi kinerja.

\section{Daftar Pustaka}

Mangkunegara, A.P(2009).Manajemen Sumber Daya Manusia. Penerbit PT. Remaja Rosdakarya Bandung

Suharsimi, A. (2009). Prosedur Penelitian Suatu Pendekatan Praktik (edisi revisi IV).Penerbit Rineka Cipta Jakarta

Amirullah.(2015).Pengantar Manajemen. Penerbit Mitra Wacana Media Jakarta

Suharsimi,A.(2009).Prosedur Penelitian Suatu Pendekatan Praktik (edisi revisi IV). PT. Rineka Cipta Jakarta

Azwar, S. (2007). Metode Penelitian. Penerbit Pustaka Belajar Yogyakarta

Azwar, S. (2008). Dasar-Dasar Psikometri. Penerbit Pustaka Belajar Yogyakarta

Azwar, S. (2008). Penyusunan Skala Psikologi. Penerbit Pustaka Belajar Yogyakarta

Azwar,S. (2009). Reliabilitas dan Validitas. Penerbit Pustaka Pelajar Yogyakarta

Bungin,H. M. B. (2005). Metode Penelitian Kuantitatif. Penerbit Kencana Prenada Media Group Jakarta

Malayu,S.P.\&Hasibuan.(2007).Manajemen Sumber Daya Manusia.Cetakan 9. Percetakan PT. Bumi Aksara Jakarta

Ega Praja Rimata. (2014). Pengaruh Komitmen Organisasi dan Motivasi Kerja Terhadap Kepuasan Kerja Karyawan PT. Pos Indonesia Yogyakarta

Luthans,F.(2006).Perilaku Organisasi (Alih Bahasa V.A Yuwono,dkk). Edisi Bahasa Indonesia, Penerbit Andi Yogyakarta

Mathis, R.L. dan Jackson, J.H.( 2002).Manajemen Sumber Daya Manusia. Penerbit PT. Salemba Empati Jakarta 
Mangkuprawira, Sjafri, Hubeis,Vitayala,A.(2007). Manajemen Mutu Sumber Daya Manusia. Penerbit Ghalia Indonesia Bogor

Mathis, Robert L., dan John H. Jackson.(2002). Manajemen Sumber Daya Manusia. Penerbit PT. Salemba Empat Jakarta

Nawari.(2010). Analisis Regresi Dengan Ms Excel 2007 dan SPSS 17.Penerbit Elex Media Komputindo Jakarta 